\title{
Cytotoxic and apoptotic effects of cyproterone acetate against cancer cells and normal cells
}

Hala M. N. Al- Saily

Mohammad M. F. Al-Halbosiy *

Faris N.A. Al-Hady

Collage of Science / University of Babylon

* Biotechnology Research Center/Al- Nahrin University

E-mail:halamohy77@g.mail.com, ma8jed@yahoo.com, drfarisabood@gmail.com

\begin{abstract}
Back ground: Cyproterone acetate (CPA) is a steroidal anti-androgen inhibits the testosterone and DHT action it is used as a medicine for prostate cancer by association with the androgen receptors located on the surface of prostate cells, thus preventing the association of testosterone with receptors. Objective: Investigation of the anticancer activities of Cyproterone acetate against cancer cell lines testicular (Tera-1), macrophage (RAW 264.7) in comparison to non- tumorigenic fetal hepatic cell line (WRL-68).

Material and method: The cytotoxic effect of CPA was investigated according to selected parameters including: MTT assay as assay of cell function to determined cell viability, high content screening (HCS) technique for the apoptosis of cell. Only the most cytotoxic concentration of CPA and the most sensitive cells as assayed by MTT was selected to complete the other test: (HCS). (MTT) assay was carried out at the Centre of Biotechnology Research's, Al- NahrainUniversityBaghdad,Iraq . The HCS assay was performed at the Centre for Natural Product Research and Drug Discovery, Department of Pharmacology,Faculty of Medicine, University of Malaya, KualaLumpur, Malaysia Results: The most significant cytotoxic effect of Cyproterone acetate towards 2 cancer cell lines was obtained when its concentration was $1.25 \mathrm{mg} / \mathrm{mL}$. The Tera-1 Cells were more sensitive to Cyproterone acetate compared with RAW264.7 and WRL-68. cells. There was a significant decrease in valid cell count, nuclear intensity and mitochondrial membrane potential (MMP) when CPA (400 $\mu \mathrm{g} / \mathrm{mL})$ was used compared with doxorubicin $(20 \mu \mathrm{g} / \mathrm{mL})$ as a standard. Also, there was a significant increase in membrane permeability and cytochrome $C$ releasing when CPA $(400 \mu \mathrm{g} / \mathrm{ml})$ was used compared with positive control.

Conclusion: CPA showed cytotoxic effects against the Tera-1 and RAW264.7 cancer cell lines while the WRL-68. Cells was not affected as determined in-vitro by the MTT assay. The HCStechnique also showed toxic effect towards Tera-1.
\end{abstract}

Key words: Cyproterone acetate, cytotoxic, apoptotic, cancer cells.

\section{Introduction}

Cyproterone acetate is a steroidal antiandrogen inhibits the testosterone and Dihydrotestosterone (DHT) action by competitive association with cellular receptors and also affects the release of lutenizing hormone (LH) from the pituitary gland and thus affects the secretion of androgen from Leydig cells (1).

Cyproterone acetate used as a medicine for prostate cancer by association with the androgen receptors located on the surface of prostate cells, thus preventing the association of testosterone with receptors (2). The chemical structure of the CPA is 6- chloro-7 $\alpha$ hydroxy $-1 \alpha 2 \alpha$ methylenepregna- 4,6 diene $-3,20$ dione acetate and its chemical form is $\mathrm{C}_{24} \mathrm{H}_{29} \mathrm{ClO}_{4}$ and its molecular weight is 416.9 Dalton, it dissolves in ethanol , methanol, benzene, and is not dissolve in water. When taken as a drug, it associated with albumin and spread in the liver, kidney, brain and heart, and subtracted from the body with gall-bladder, urine and milk (2). Cyproterone acetate is a potent androgen receptor antagonist and potent antigonadotropin as well as a weak androgen synthesis inhibitor $(3,4)$.

Cyproterone acetate is used as one of the prostate cancer treatments given with a daily dose of $300 \mathrm{mg}(2)$, as well as for the treatment of acne (5), hairstizum and polycystic ovarian syndrome (PCOS) in women (1). It is also used as a contraceptive in women through its effect on the release of LH, thus lack of ovulation. It can be used as antifertility drug for men by controlling the FSH hormone and by its acting to decrease the process of cellular division of spermatid and decrease the diameter of seminifeurous tubules, it also interfere with the process of completing the formation of the sperm, espicially the process of forming the cover at the sperm cap phase, and also inhibits the spermatogenesis especially the last stages of meosis (6), in addition to its effect in vas defferense as it affect the $\alpha 1$ - adrenoreceptor sub type receptors (7).

Materials and methods

Preparation of CPA

CPA was prepared according to (8) method. 


\section{Determined of Cytotoxicity}

The cytotoxic effect of CPAwas investigated according to selected parameters including: MTT assay as assay of cell function to determined cell viability, high content screening (HCS) technique for the apoptosis of cell. Only the most cytotoxic concentration of CPA and the most sensitive cells as assayed by MTT was selected to complete the other test: (HCS)

\section{3-(Dimethylthiazol-2-yl)-2,5Diphenyltetrazoliumbromid assay (MTTassay)}

The cell viability was determined by colorimetric assay using 3-(4,5-dimethylthiazoyl)-2,5diphenyltetrazolium bromide (MTT dye), and the cells viability percent was estimated according to (9) procedure

The data of optical density were subjected to statistical analysis in order to calculate the concentration of CPA cause a $50 \%$ reduction in cell viability for each cell line (10).

\section{The High Content Screening (HCS) Assay}

The multi- parameters cytotoxicity assay was performed according to (11) method by using the HCS kit to measurement of five independent parameters that monitor cell death, including viability cell count, nuclear size and morphological changes (nuclear intensity), changes in cell membrane integrity and cell permeability, mitochondrial membrane potential and cytochrome $\mathrm{C}$ localization, release from mitochondria. Different concentrations of CPA , 100, 200, and $400 \mu \mathrm{g} / \mathrm{ml}$ were used for treatment one cell line: the human testes cancer cell lines (Tera-1) for interval time 24 hours.

\section{Tera-1 cell preparation}

The protocol of Tera-1 cells was optimized according to the instruction of ATCC (American Type Culture Collection). EMEM medium containing $10 \%$ fetal bovine serum and 100 units $/ \mathrm{ml}$ pencillium and 100 $\mu \mathrm{lg} / \mathrm{ml}$ streptomycin were used for routine culture.

\section{Statistical Analysis}

Statistical Package for Social Science (SPSS) system/ version 23 was used to perform the analysis of data. Results expressed as mean \pm S.D. The Analysis of Variance (ANOVA), the Least Significant Difference (LSD) test and Duncan was used to compare between means.

\section{Results and Discussion \\ Cytotoxic effect of CPA on cancer cell lines and normal cells in vitro by using MTT assay}

The cytotoxic effect was determined by 3-(dimethylthiazol-2-yl)-2,5-diphenyltetrazolium bromid (MTT) assay on two different types of tumor cell lines: tastis cancer cell lines Tera-1, macrophage cancer cell lines RAW264.7 and normal hepatic cells WRL-68. This assay was performed to measure the cell viability by applying different concentrations of CPA on the tumor and normal cell lines Table (1). MTT colorimetric assay was achieved to determine cell viability at each time- point (24h.), best values were chosen for the most significant IC50 values Figure (1), Figure (2) and Figure (3).

The results indicated that the incubation of RAW264.7 cells and Tera- 1 cells with CPA in concentrations $0.0175,0.039,0.078,0.156,0.312,0.625$ and $1.25 \mathrm{mg} / \mathrm{ml}$ for 24 hours showed a reduction in cells viability in a dose dependent pattern by which cell viability decreased by increasing the concentrations of CPA. The lowest cell viability was recorded in Tera-1 cells $20.79 \%$ in concentration $1.25 \mathrm{mg} / \mathrm{ml}$; however it was $32.34 \%$ and $76 \%$ for RAW264.7 and WRL- 68, respectively at $1.25 \mathrm{mg} / \mathrm{ml}$. The results showed that the WRL-68 cells viability was not significantly affected by the application of different concentrations of CPA as compared with the viability of Tera-1 and RAW246.7 cells. It was observed significant differences in the cell viability $\%$ between the different cell lines by calculating the IC50. The tera- 1 significantly affected by the cytotoxic activity of CPA with IC50 $0.221 \mathrm{mg} / \mathrm{ml}$, whereas IC50 values of RAW246.7 and WRL-68 were $0.421 \mathrm{mg} / \mathrm{ml}$ and $23.49 \mathrm{mg} / \mathrm{ml}$, respectively.

From all results it was found that the CPA was effective on all cancer cell lines used in this study and Tera- 1 cells were more sensitive to the CPA than RAW264.7 cells, whereas the WRL-68 cells were not affected by CPA. 
Table (1): Cytotoxicity effect of CPA on RAW264.7 cells, Tera-1 cells and WRL-68 cells after 24 hours incubation at $37^{\circ} \mathrm{C}$

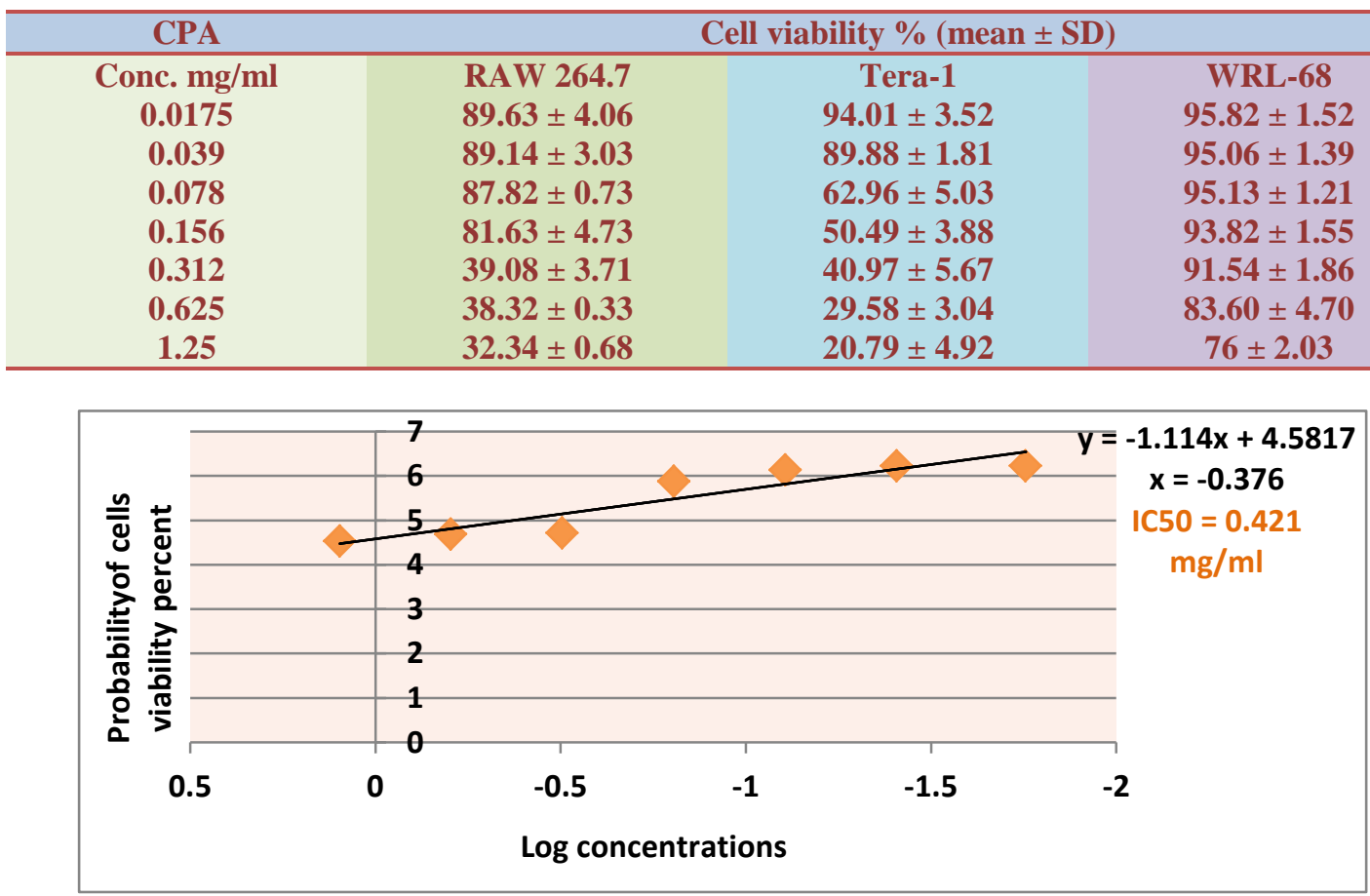

Figure (1): IC50 of CPA- treated RAW264.7 cells after 24 hours of incubation

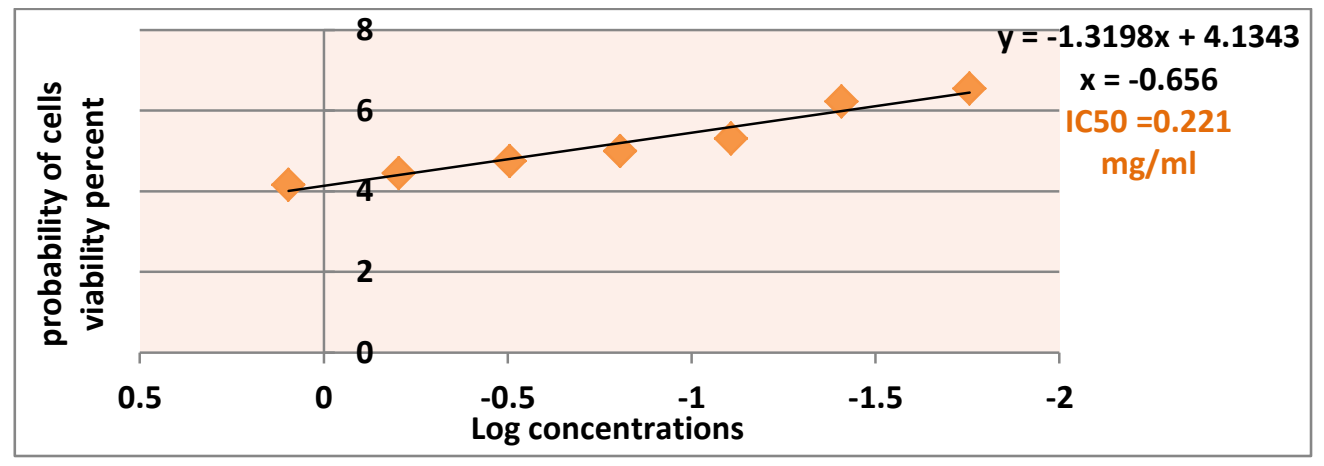

Figure (2): IC50 of CPA- treated Tera-1 cells after 24 hours of incubation

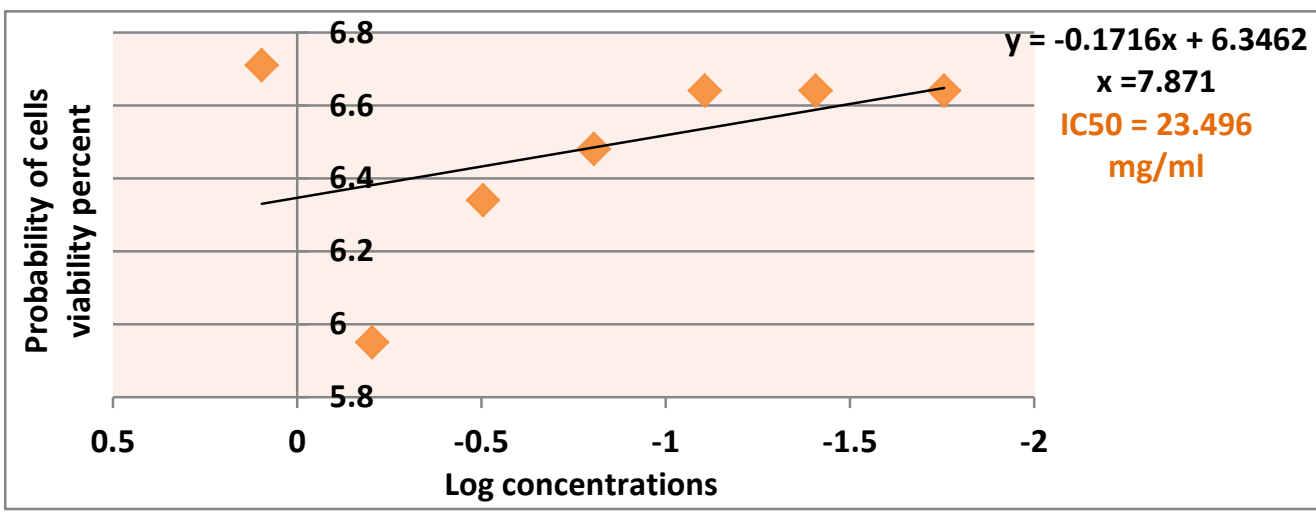

Figure (3): IC50 of CPA- treated WRL-68 cells after 24 hours of incubation 
CPA increase the oxidative stress state and generating free radicals in test system (12). The cytotoxic effect of CPA on Tera-1 and RAW264.7 cell lines may be attributed to increased oxidative stress and free radicals induce apoptosis in testicular germ cells in vitro by increased expression of apoptosis signaling pathways that involved extrinsic (Fas, Fasl and caspase-8) and intrinsic (Bid, Bad, Bax and caspase-9) pathways (13). This finding was agreed with the results of Chen, et al (14), which revealed that the free radicals caused a marked decrease in cells viability of RAW264.7 cells and this decrease was dose dependent. As well as Zhang et al (15) suggested that the treatment of RAW264.7 cells with $\mathrm{H}_{2} \mathrm{O}_{2}$ caused up- regulation of stress and apoptosis related genes and low-regulation of cell cycle and growth promoting genes, glycolysis and lipid synthesis related genes.

The results of current study showed that the IC50 of Tera-1 cells was $0.221 \mathrm{mg} / \mathrm{ml}$ and IC50 of RAW264.7 was $0.421 \mathrm{mg} / \mathrm{ml}$, the reason may be due to that the testicular cells are more sensitive to CPA than the macrophage cells because of their intensive sensitivity to the free radicals that induced apoptosis (13), in these cells more than macrophage cells, whereas the normal hepatic cells was not affected by CPA where IC50 of WRL-68 was $23.496 \mathrm{mg} / \mathrm{ml}$, the reason may be due to fact that cancer cells under increased intrinsic reactive oxygen species (ROS) stress more than normal cells, this provide a unique opportunity to kill the cancer cells based on their vulnerability to further ROS insults and amplify ROS stress in cancer cells (16).

\section{The Multi- Parameters Cytotoxicity Activity of CPA on Tera-1 cell line}

The multi- parameters-cytotoxic activity of CPA was achieved by High Content Screening (HCS) which is cellular imaging-based procedure that played an important role in the detection of toxicity of compounds by observed patterns of reversible and irreversible cellular damage. HCS provides multi-parameters for analysing the toxicity of the compound at the individual cell level (17).

Three concentrations of $100,200,400 \mu \mathrm{g} / \mathrm{ml}$ of the CPA were tested on Tera- 1 cell line to detect the changes in five cellular parameters (valid cell count, nuclear intensity, membrane permeability, mitochondrial membrane potential and cytochrome $\mathrm{C}$ releasing) after 24 hours of exposure.

Table (2) showed that $400 \mu \mathrm{g} / \mathrm{ml}$ concentration has the highest significant effect on all five cellular parameters (valid cell count, nuclear intensity, membrane permeability, mitochondrial membrane potential and cytochrome $\mathrm{C}$ releasing), when compared with Doxorubicin $20 \mu \mathrm{M}$ (substance used as anti-cancer) which represent the positive control. Concentration of $100 \mu \mathrm{g} / \mathrm{ml}$ showed results close to those of the untreated cells which represent the negative control. Results indicated that the incubation of Tera- 1 cells with CPA at concentrations of 100, 200 and $400 \mu \mathrm{g} / \mathrm{ml}$ for 24 hours showed a significant decrease $(p<0.05)$ in valid cell count, nuclear intensity and mitochondrial membrane potential (MMP) and a significant increase $(p<0.05)$ in membrane permeability and cytochrome $\mathrm{C}$ releasing as compared to negative control (untreated) in dose dependent pattern by which the decrease of valid cell count, nuclear intensity and mitochondrial membrane potential and increased membrane permeability and cytochrome $\mathrm{C}$ releasing by increasing the concentration of CPA.

Table (2): Cytotoxicity effect of Cyproterone acetate (CPA) on multi cellular parameters of Tera-1 cell line after 24 hurs incubation at $37 c^{\circ}$ and evaluated on the Array Scan HCS Reader

\begin{tabular}{|c|c|c|c|c|c|}
\hline \multicolumn{6}{|c|}{ HCS parameters (mean \pm SD) } \\
\hline $\begin{array}{c}\text { Concentrations } \\
\mu \mathrm{g} / \mathrm{ml}\end{array}$ & Valid cell count & Nuclear intensity & $\begin{array}{l}\text { Membrane } \\
\text { permeability }\end{array}$ & MMP $*$ & $\begin{array}{c}\text { Cytochrome } \mathbf{C} \\
\text { releasing }\end{array}$ \\
\hline $\begin{array}{c}\text { Control } \\
\text { (untreated) }\end{array}$ & $\begin{array}{c}2069 \pm 4.24 \\
a\end{array}$ & $\begin{array}{c}304.3 \pm 14.07 \\
\text { a }\end{array}$ & $\begin{array}{c}80.55 \pm 11.38 \\
\text { a }\end{array}$ & $\begin{array}{c}320.4 \pm 7.92 \\
\text { a }\end{array}$ & $\begin{array}{c}157.9 \pm 6.57 \\
a\end{array}$ \\
\hline $\begin{array}{c}\text { Doxorubicin } \\
20 \mu \mathrm{M}\end{array}$ & $\begin{array}{c}1261 \pm 9.89 \\
d\end{array}$ & $\begin{array}{c}160.9 \pm 4.17 \\
b\end{array}$ & $\begin{array}{c}162.8 \pm 5.95 \\
c\end{array}$ & $\begin{array}{c}186.4 \pm 4.45 \\
d\end{array}$ & $\begin{array}{c}269.9 \pm 7.28 \\
d\end{array}$ \\
\hline 100 & $\begin{array}{c}1898 \pm 7.77 \\
\text { b }\end{array}$ & $\begin{array}{c}281 \pm 7.63 \\
a\end{array}$ & $\begin{array}{c}99 \pm 8.91 \\
a\end{array}$ & $\begin{array}{c}287.8 \pm 6.15 \\
\text { b }\end{array}$ & $\begin{array}{c}173.3 \pm 4.59 \\
\text { a }\end{array}$ \\
\hline 200 & $\begin{array}{c}1743 \pm 59.40 \\
\text { c }\end{array}$ & $\begin{array}{c}261.2 \pm 11.38 \\
\text { a }\end{array}$ & $\begin{array}{c}111.5 \pm 11.38 \\
b\end{array}$ & $\begin{array}{c}251.8 \pm 6.01 \\
\text { c }\end{array}$ & $\begin{array}{c}191 \pm 6.57 \\
b\end{array}$ \\
\hline 400 & $\begin{array}{c}1422 \pm 18.38 \\
\text { d }\end{array}$ & $\begin{array}{c}179.3 \pm 10.32 \\
\text { b }\end{array}$ & $\begin{array}{c}142.6 \pm 6.50 \\
c\end{array}$ & $\begin{array}{c}201.7 \pm 4.73 \\
d\end{array}$ & $\begin{array}{c}219.7 \pm 6.15 \\
\text { c }\end{array}$ \\
\hline
\end{tabular}

Different letters refer to the significant difference $(p<0.05)$ between groups

Similar letters refer to the non- significant difference $(p>0.05)$ between groups

MMP = mitochondrial membrane potential. 
The reduction in valid cells count of Tera-1 cell line was correlated to the toxic effect of CPA. In a study done by Lippman et al (18) to detect the anti- cancer activity of CPA on human breast cancer cells, and a study done by Chen et al (19) to detect anti- cancer activity of CPA on prostate cancer cells and DU145, it were found that the CPA inhibits the growth of these three cell lines in different rates depending on cell line type, concentrations and exposure period.

Apoptosis involved chromatin condensation and nuclear fragmentation then decreasing nuclear intensity as the fragmentation increased (20). In a study on human peripheral blood cells reported that the treatment with CPA induces DNA damage in these cells which is an indicator of apoptosis $(21,22)$.

It has been reported that changes in cell membrane permeability often associated with a toxic or apoptotic response, and the loss of cell membrane integrity is a common phenotypic feature of marked cytotoxicity (23).

The decrease in mitochondrial membrane potential (MMP) and triggering apoptosis of Tera-1 cells may be attributed to the down regulation of $\mathrm{Bcl}-2$ anti-apoptotic gene and increase Bax and caspase-9 which are considered apoptotic signals to initiate intrinsic pathway of apoptosis in testicular germ cells in vitro treated with cell with CPA $(13,24)$, these events lead to changes in the membrane potential which is due to the opening the mitochondrial permeability transition pore and allowing transition of ions and small molecules such as calcium ions, this leads to the decoupling of the respiratory chain and release the cytochrome $\mathrm{C}$ in to the cytosol (25). Finally the cytochrome $\mathrm{C}$ release activates caspase- 9 which leading to caspase- 3 formation and cysteine protease activation, which are mainly responsible for degradation and digestion of the cell from inside $(26,27)$.

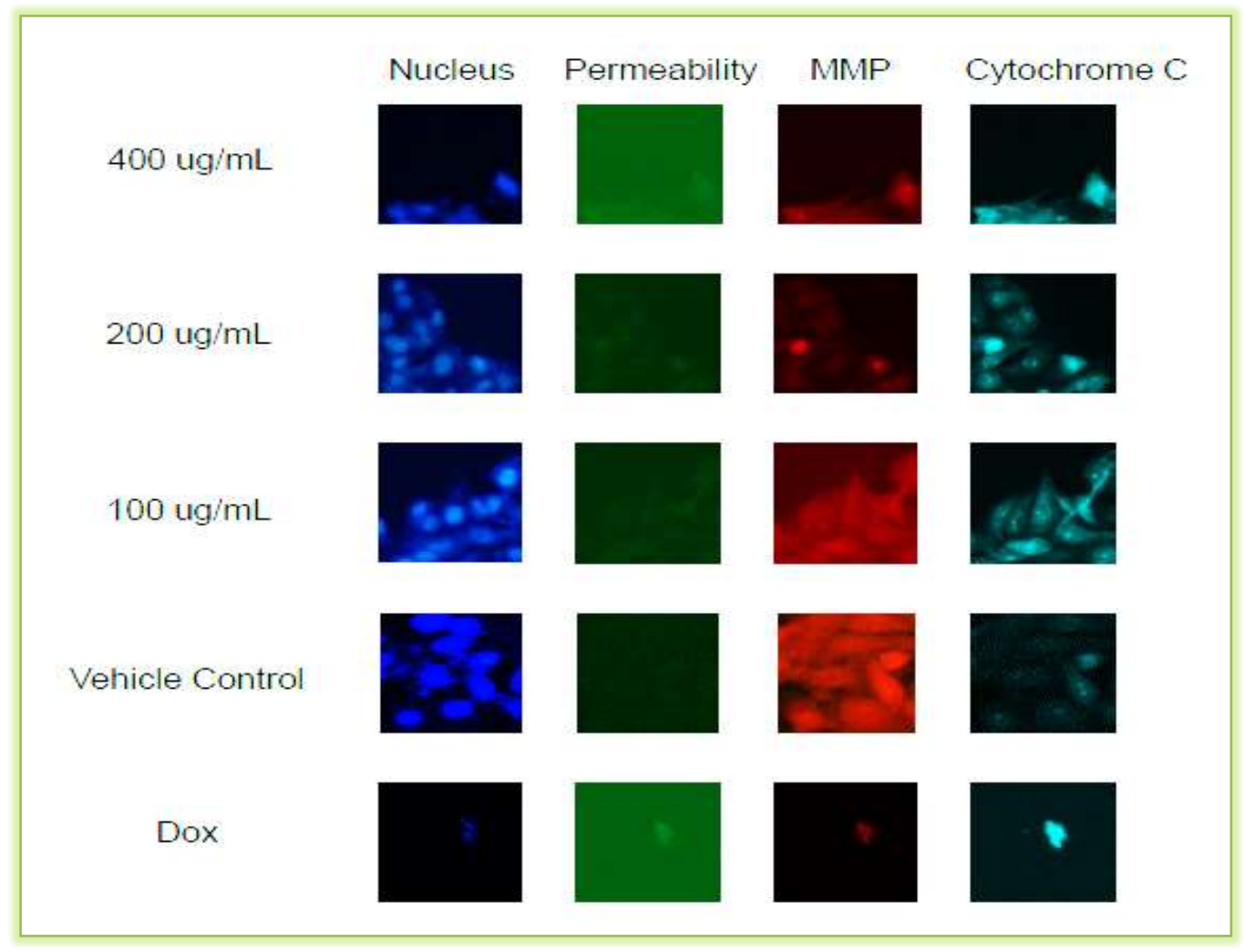

Figure (4): Effect of CPA on multicellular parameters of Tera-1 cell line after 24 hours of incubation at $37^{\circ} \mathrm{C}$ and evaluated on the Array Scan HCS reader 


\section{References}

1. Falsetti L, Gambera A, Tisi G. Efficincy of combination ethinyl oestradiol and cyproterone acatate on endocrine, clinical and ultrasonographic profile in polycystic ovarian syndrome.Oxford J.s.(2001);16 (1): 36-42.

2. Hellerstedt BA, Pienta KJ. The current state of Hormonal . Therapy for prostate cancer. CA Cancer J. Clin. (2002); 52: 154-179.

3. Hanna L, Crosby T, Macbeth F. Practical Clinical Oncology. Cambridge University Press. (2015);37.

4. Weber GF. Molecular Therapies of Cancer. Springer. (2015); 314-316.

5. Iraji F, momeni A, Naji SM, siadat AH. The efficacy of topical cyproterone acetate alcohol lotion versus placebo in the treatment of the mild to moderate acne vulgaris: a double blind study. Dermatology online J. (2006); 12 (3):26.

6. Kula K. The influence of human menopausal gonadotropin, natrium fluoride and cyproterone acetate on the spermatogenesis in immature rats. Andrologia. (1978); 10(3): 223-33.

7. Campos M, morais PL, pupo AS. Effect of cyproterone acetate on a Lphal-adrenoceptor subtypes in rat vasdeferens . Brazilian J. of Medical and Biological Research. (2003); 36: 1571-1581.

8. Abd-Al-Ameer EH. The effects of Cyproterone acetate on the sexual performance and fertility on the white Rats Rattus rattus .Athesis of ph.d,college of science- University of Babylon. (2008);(in arabic).

9. Chih PL, Wei JT, Yuang LL, Yuh CK. The extracts from Nelumbonucifera suppress cell cycle progression, cytokine genes expression, and cell proliferation in human peripheral blood mononuclear cells.Life Science.(2004); 75, :699-716.

10. Freshney RI. Culture of Animal Cell. Sixth Edition.Wily-Liss.(2012);New York.

11. Diana M, Adirele PM, Yuri V, Silvia G. Determination of Spiropyran cytotoxicity by High Content Screening (HCS) and analysis for safe application in bionanosensing.Chemical Researches Toxicology.(2012);23: 1459-1466.

12. Siddique $\mathrm{YH}$, Afzal M. Genotoxic potential of cyproterone acetate: a possible role of reactive oxygen species. Toxicology In vitro, (2005); 19: 63-8.

13. Maheshwari A, Misro MM, Aggarwal A, Sharma RA, Nandan D. Pathways involved in testicular germ cells apoptosis induced by $\mathrm{H}_{2} \mathrm{O}_{2}$ in vitro. The FEBS J.(2009); 276(3):870-881.

14. Chen YW, Hwang KC, Yen CC, Lai YL. Fullerene derivatives protect against oxidative stress in RAW 264.7 cells and ischemia-reperfused lungs. American J. of physiology- Regulatory, Integrative and comparative physiology. (2004); 287(1):21-26.

15. Zhang Y, Fong CC, Wong MS, Tzang CH, Lai WP, Fong WF, Sui SF, Yang M. Molecular mechanisms of survival and apoptosis in RAW 264.7 macrophages under oxidative stress. Springer. (2005);10(3):545-556.

16. Pelicano H, Carney D, Huang P. ROS stress in cancer cells and therapeutic implications. Drug Resistance Updates. (2004); 7:97-110.

17. Abraham VC, Towne DL, Jeffery TFW, Warrior S, David JB. Application of a high-content Multiparameter Cytotoxicity Assay to Prioritize Compounds Based on Toxicity Potential in Humans .J. of Biomolecular Screening. (2008); 13:527.

18. Lippman M, Bolan G, Huff $K$. The effect of androgens and antiandrogens on hormone response human breast cancer in long- term tissue culture. Cancer research. (1976); 36:4610-4618.

19. Chen L, Wolff DW, Xie Y, Lin MF, Tu Y. Cyproterone acetate enhances TRAIL-induced androgenindependent prostate cancer cell apoptosis via up- regulation of death receptors 5. BMC cancer. (2017); 17(179):1-11.

20. Mohammed, Zainab Yassen. Phytochmical and Molecular Investigation of ActiveConstituents of Lycium barbarum on Normanl Human Blood Lymphocytes and Cancerous Cells.Ph.D. thesis, college of science, University of Baghdad (2013).

21. Siddique YH, Afzal M. Induction of chromosomal aberration and sister chromatid exchanges by chlomadinone acetate in human lymphocytes: a possible role of reactive oxygen species. Indian J. of Experimental Biology. (2004); 42:1078-83.

22. Siddique $\mathrm{YH}$, Ara G, Beg T, Afzal M. Genotoxic potential of medroxyprogesterone acetate in cultured human peripheral blood lymphocytes. Life Science. (2006); 80: 212-8.

23. Al- Tameme, Hajar Falih Hishan Raja In Vitro cytotoxic and antioxidant activity of Pelargonium graveolens leaves extracts on various human tumor cell lines. Msc. thesis, college of science, Tikrit University (2016).

24. Tripathy A, Ghosh A, Dey A, Pakhira BP, Ghosh D. Attenuation of the Cyproterone acetateinduced testicular hypofunction by a novel nutraceutical lycopene: a genomic approach. Andrologia. (2017); 49(8):127-9. 
25. Susin SA, Zamzami N, Kroemer G. Mitochondria as regulators of apoptosis: doubt no more. Biochim. Biophys. Acta. (1998); 1366(1-2):151-165.

26. Tafani M, Karpinich NO, Hurster KA, Pastorino JG, Schneider T, Russo MA. Cytochrome c release upon Fas receptor activation depends on translocation of full-length bid and the induction of the mitochondrial permeability transition. J. Biol. Chem. (2002); 277 (12): 10073-10082.

27. Cha JD, Kim YH, Kim JY. Essential oil and 1, 8 -cineole from Artemisia lavandulaefolia induces apoptosis in KB Cells via mitochondrial stress and caspase activation. Food Science and Biotechnology. (2010); 19(1):185-191. 